\title{
Pengungkapan Penerapan Corporate Social Responsibility pada Hotel Aston Kuta
}

\author{
Kusnadewi ${ }^{1}$ \\ Fakultas Ekonomi dan Bisnis \\ Universitas Udayana, Indonesia
}

\section{Dewa Gede Dharma Suputra ${ }^{2}$ \\ Fakultas Ekonomi dan Bisnis \\ Universitas Udayana, Indonesia}

\begin{abstract}
Surel : malaikatkembar@gmail.com
ABSTRAK

Dewasa ini masyarakat dan perusahaan makin menyadari pentingnya kegiatan pelestarian lingkungan, perbaikan taraf ekonomi maupun keharmonisan sosial. CSR adalah salah satu cara untuk menujukkan kepedulian perusahaan terhadap lingkungan dan masyarakat di sekitarnya. Kegiatan Corporate Social Responsibility (CSR), atau disebut juga Social Activity ataupun sering disebut Sustainability Development bukanlah pengungkapan perilaku sebuah individu dalam perusahaan tetapi merupakan pengungkapan perilaku perusahaan yang dapat meningkatkan kepercayaan sosial terhadap perusahaan. Kegiatan Corporate Social Responsibility (CSR) bagi sebuah hotel tidak secara langsung meningkatkan laba perusahaan, tetapi dengan melaksanakan kegiatan tersebut dalam lingkungan maupun di masyarakat sekitar, maka hal itu akan meningkatkan citra perusahaan di mata publik. Ada berbagai macam kegiatan yang dapat dikatagorikan sebagai bagian dari CSR, mulai dari promosi dan pemasaran kegiatan sosial, kegiatan filantropi (derma), pekerjaan sosial/kemasyarakatan.
\end{abstract}

Kata Kunci: Corporate Social Responsibility (CSR); Pengungkapan Perilaku Perusahaan; Meningkatkan Citra Perusahaan di Mata Publik; Kegiatan yang Dapat Dikatagorikan sebagai Bagian dari CSR.

\section{Disclosure of the Application of Corporate Social Responsibility on Aston Kuta Hotel}

\begin{abstract}
Nowadays, society and companies are increasing aware of the importance of environmental conservation of activities, improvement of economic standards and social harmony. CSR is away to show the company's concern for the environment and the suroounding community. Corporate Social Responsibility (CSR) activities, or also known as Social Activities or often called Sustainability Development, are not a disclosure of the behavior of an individual in a company but are a disclosure of corporate behavior that can increase social trust in the company. Corporate Social Responsibility (CSR) activities for a hotel do not directly increase company profits, but by carrying out these activities in the environment and in the surrounding community, it will improve the company's image in the eyes of the public. There are various kinds of activities that can be categorized as part of CSR, from the promotion and marketing of social activities, philanthropic activities (charity), voluntary social/ community work.
\end{abstract}

Keywords: Corporate Social Responsibility (CSR); Disclosure of Corporate Behavior; Improve The Company's Image In The Eyes of The Public; Various Kinds Of CSR.

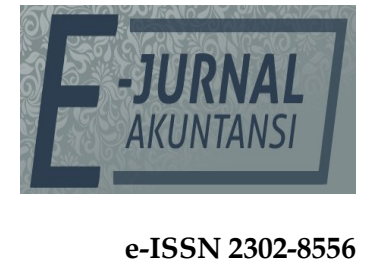

Vol. 31 No. 7

Denpasar, Juli 2021

Hal. 1680-1691

10.24843/EJA.2021.v31.i07.p06

PENGUTIPAN:

Kusnadewi., \& Suputra, D.G.D. (2021). Pengungkapan

Penerapan Corporate Social Responsibility pada Hotel Aston Kuta. E-Jurnal Akuntansi, 31(7), 1680-1691

RIWAYAT ARTIKEL: Artikel Masuk: 27 November 2020 Artikel Diterima: 5 April 2021

Artikel dapat diakses : https://ojs.unud.ac.id/index.php/Akuntansi/index 


\section{.}

\section{PENDAHULUAN}

Perusahaan adalah salah satu penyumbang terbesar terhadap berbagai dampak yang terjadi baik di lingkungan sekitarnya maupun di masyarakat.Dampak tersebut dapat berupa dampak lingkungan, ekonomi maupun sosial budaya. Masyarakat dan perusahaan mulai menyadari arti penting dari berbagai kegiatan yang memberikan dampak positif baik untuk pelestarian lingkungan, perbaikan taraf ekonomi maupun keharmonisan sosial. Corporate Social Responsibility (CSR) merupakan salah satu cara untuk menujukkan kepedulian perusahaan terhadap lingkungan dan masyarakat di sekitarnya.

Peningkatan terhadap pengungkapan Corporate Social Responsibility (CSR) di berbagai Negara melalui laporan Corporate Social Responsibility (CSR) (Chou et al., 2017). Diperkirakan 95 persen dari 250 perusahaan besar di dunia telah mengungkapkan laporan Corporate Social Responsibility (CSR). Hal ini menunjukkan bahwa perusahaan mulai menyadari keterkaitan antara Corporate Social Responsibility (CSR) dengan performa keuangan perusahaan. Corporate Social Responsibility (CSR) merupakan salah satu pendorong terbesar untuk meningkatkan daya saing sehingga bukan lagi merupakan sekedar langkah sosial tetapi sebagai alat untuk mendapatkan pengakuan dan penghargaan dari masyarakat/publik yang berimplikasi pada peningkatan pendapatan.

Kegiatan Corporate Social Responsibility (CSR), atau disebut juga Social Activity ataupun sering disebut Sustainability Development bukanlah pengungkapan perilaku sebuah individu dalam perusahaan tetapi merupakan pengungkapan perilaku perusahaan yang dapat meningkatkan kepercayaan sosial terhadap perusahaan (Adeneye \& Ahmad, 2015). Aktivitas Corporate Social Responsibility (CSR) menunjuk pada berbagai kegiatan sosial yang melampaui batas lingkungan perusahaan (Kitzmueller \& Shimshack, 2012). Perusahaan mengungkapkan Corporate Social Responsibility (CSR) dengan mempromosikan berbagai hal sosial yang diminati oleh masyarakat yang dapat membangun dan meningkatkan hubungan antara perusahaan dengan masyarakat maupun pihak lain (Hossain et al., 2013). Perusahaan bekerja sama dengan masyarakat dan lingkungan, karena dari lingkungan sekitar perusahaan mendapatkan pelanggan, pemasok, pekerja, investor, dan stakeholders yang secara langsung maupun tidak langsung berpengaruh terhadap keberadaan perusahaan itu sendiri (Bhuiyan et al., 2015). Pengungkapan Corporate Social Responsibility (CSR) dapat membangun sebuah konsep bahwa perusahaan peduli terhadap lingkungannya karena pengaruh atau efek yang diakibatkan oleh perusahaan terhadap lingkungan dan masyarakat (Ismail, 2014). Pencemaran lingkungan dan limbah produksi adalah satu contoh kecil dari dampak yang ditimbulkan oleh perusahaan terhadap lingkungannya, sehingga melalui kegiatan Corporate Social Responsibility (CSR) yang dilakukan perusahaan dapat mengurangi efek tersebut terhadap lingkungannya sekaligus meraih kepercayaan masyarakat (Suartana, 2010). Kegiatan Corporate Social Responsibility (CSR) yang dilakukan oleh perusahaan akan membangun ikatan yang kuat dengan stakeholders, sehingga secara otomatis perusahaan akan lebih berdaya saing (Battaglia et al., 2014).

Pandangan dan penghargaan terhadap berbagai kegiatan Corporate Social Responsibility (CSR) di Indonesia mulai mengalami peningkatan. Tahun 2005, tercatat sebagai tahun dimana Corporate Social Responsibility (CSR) telah mencapai 
momentum di Indonesia dengan diadakannya Corporate Social Responsibility (CSR) Award. Pada tahun 2007, kegiatan Corporate Social Responsibility (CSR) telah mulai diatur dengan dikeluarkannya Undang-Undang Perseroan Terbatas. Pasal 74 ayat (1) UU 40 tahun 2007, yang menjelaskan bahwa perseroan yang menjalankan kegiatan usahanya di bidang dan/atau berkaitan dengan sumber daya alam, wajib melaksanakan tanggung jawab sosial dan lingkungan. Mengapa perlu suatu program Corporate Social Responsibility (CSR) diatur dalam undang-undang khusus dimaksudkan untuk menghindari perusahaan agar tidak menjalankan keputusan yang merugikan masyarakat dan lingkungan demi keuntungan perusahaan itu yang sebesar-besarnya. Pembuatan undang-undang ini juga dimaksudkan agar ada peraturan yang jelas mengenai lingkup dari Corporate Social Responsibility (CSR). Perusahaan yang bergerak di bidang jasa terutama perhotelan, melakukan banyak cara untuk menerapkan Corporate Social Responsibility (CSR), mulai dari yang sederhana yaitu menghimbau tamu untuk tidak mengganti handuk setiap hari, hingga tindakan permanen yaitu menggunakan konstruksi bangunan yang ramah lingkungan, penyediaan air panas utk kebutuhan tamu didapat dari solar system sehingga tidak banyak menggunakan listrik (Rio, 2010). Pembangunan gedung dengan menggunakan kontruksi bangunan yang ramah lingkungan seperti di Bali, pemeliharaan taman hotel yang tidak menggunakan pestisida serta beberapa produk yang dapat didaur ulang, kegiatan bakti sosial seperti pelepasan tukik di pantai, menujukkan tindakan nyata yang dilakukan pelaku bisnis tersebut baik industri perhotelan maupun industri lain, bisa dikategorikan sebagai level atau tahap dari pelaksanaan Green management yang disebut sebagai Green Approaches (Robbins et al., 2012).

\section{METODE PENELITIAN}

Penelitian ini menggunakan pendekatan kualitatif yaitu data yang dapat dikumpulkan, diolah kemudian dijabarkan dan diinterpretasikan. Hariwijaya, (2017) mendefinisikan penelitian kualitatif sebagai penelitian yang tidak menggunakan model-model matematik, statistik atau komputerisasi. Proses penelitian dimulai dengan menyusun asumsi dasar dan aturan berpikir yang akan digunakan dalam penelitian. Asumsi dasar dan aturan berpikir tersebut selanjutnya akan diterapkan secara sistematis dalam pengumpulan dan pengolahan data untuk memberikan penjelasan dan argumentasi. Informasi yang dikumpulkan dan diolah harus tetap obyektif dan tidak dipengaruhi oleh pendapat peneliti sendiri. Penelitian dilakukan pada Hotel Aston Kuta yang berlokasi di Jalan Kediri Tuban Kuta. Pengambilan lokasi Hotel Aston Kuta sebagai lokasi penelitian disebabkan oleh beberapa faktor. Pertama, Hotel Aston Kuta berada di kawasan utama destinasi wisata yaitu Kuta dan bergerak di bidang industri jasa pariwisata. Hotel Aston Kuta terletak di jantung kawasan wisata Kuta yaitu di sekitar kawasan pantai Kuta. Obyek penelitiannya adalah pengaruh yang timbul sebagai akibat penerapan Corporate Social Responsibility (CSR) dalam hal ini terkait dengan profitabilitas, masyarakat sekitar dan lingkungan, sesuai dengan konsep triple botoom line. Sumber data primer dalam penelitian ini berupa catatan hasil wawancara yang diperoleh melalui wawancara yang peneliti lakukan dengan pihak perusahaan yaitu ketua tim Corporate Social Responsibility (CSR) dan timnya. Sumber data sekunder dalam penelitian ini adalah berupa dokumen- 
dokumen penting seperti laporan kegiatan CSR. Penelitian kualitatif tidak menggunakan populasi karena penelitian kualitatif berangkat dari kasus tertentu pada situasi sosial tertenti. Sampel dalam penelitian kualitatif tidak dinamakan dengan responden tetapi nara sumber atau informan. Sampel dalam penelitan kualitatif tidak disebut sebagai sampel statistik tetapi sampel teoritis (Sugiyono, 2015).

Teknik pengumpulan data yang digunakan dalam penelitian ini adalah Metode wawancara, yaitu merupakan pertemuan dua orang untuk bertukar informasi dan ide melalui tanya jawab, sehingga dapat dikonstruksikan makna dalam suatu topik tertentu. Wawancara yang digunakan adalah wawancara tidak terstruktur yaitu menggunakan percakapan informal. Metode dokumentasi yaitu metode pengumpulan data dengan pengumpulan dokumen yang berbentuk tulisan, misalnya catatan harian, sejarah kehidupan (life histories), cerita, biografi, peraturan kebijakan. Dokumen yang berbentuk gambar, misalnya foto, gambar hidup, sketsa dan lain-lain (Sugiyono, 2015). Peneliti mengumpulkan data-data berupa laporan keuangan, catatan aktifitas mengenai Corporate Social Responsibility (CSR), foto-foto kegiatan Corporate Social Responsibility (CSR) dan beberapa informasi dari website mengenai Corporate Social Responsibility (CSR) yang dilakukan oleh Hotel Aston Kuta. Analisis data dalam penelitian ini dilakukan secara interaktif dan berlangsung secara terus-menerus sampai selesai (Sugiyono, 2015). Dalam analisis data, peneliti ikut terlibat langsung dalam menjelaskan dan menyimpulkan data yang diperoleh dengan mengkaitkan teori yang digunakan. Analisis data dalam peneltian ini menggunakan model Miles dan Huberman yang terdiri dari tiga alur kegiatan yang terjadi secara bersamaan, yaitu reduksi data, penyajian data dan penarikan kesimpulan atau verifikasi.

\section{HASIL DAN PEMBAHASAN}

Hotel Aston Kuta adalah hotel dengan katagori bintang empat yang berlokasi di Kuta. Hotel tersebut beroperasi sejak tanggal 1 September 2009 dan menjadi salah satu hotel terbaik di kawasan Kuta. Pendiri Hotel Aston Kuta bernama Njoo Daniel Dino Dinata. Hotel Aston Kuta yang bernaung di bawah Aston International. Aston International mengumumkan perubahan nama perusahaan menjadi Archipelago International pada 22 Januari 2013. Identitas resmi baru perusahaan itu akan menaungi organisasi perusahaan dan menjadi nama dari manajemen perusahaan untuk seluruh hotel dan resor yang sudah beroperasi maupun yang akan dibuka. Hotel Aston Kuta menawarkan akomodasi modern dengan sentuhan Bali klasik. Berjarak kurang lebih 5 menit dari bandara Internasional Ngurah Rai dan berlokasi di Jalan Wana Segara Kuta yang dekat dengan kawasan wisata Pantai Kuta. Hotel Aston memiliki 209 kamar dengan 4 (empat) katagori atau tipe kamar yaitu Superior, Deluxe Family dan Premiere Suite.

Kegiatan atau pelaksanaan CSR pada Hotel Aston Kuta dikoordinasikan oleh Departemen Sumber Daya Manusia/SDM (Human Resources Departemen) yang langsung dipimpin oleh Human Resources Director dan dipertanggungjawabkan langsung kepada General Manager Hotel. Struktur pelaksana kegiatan CSR pada Hotel Aston Kuta adalah sebagai berikut. 


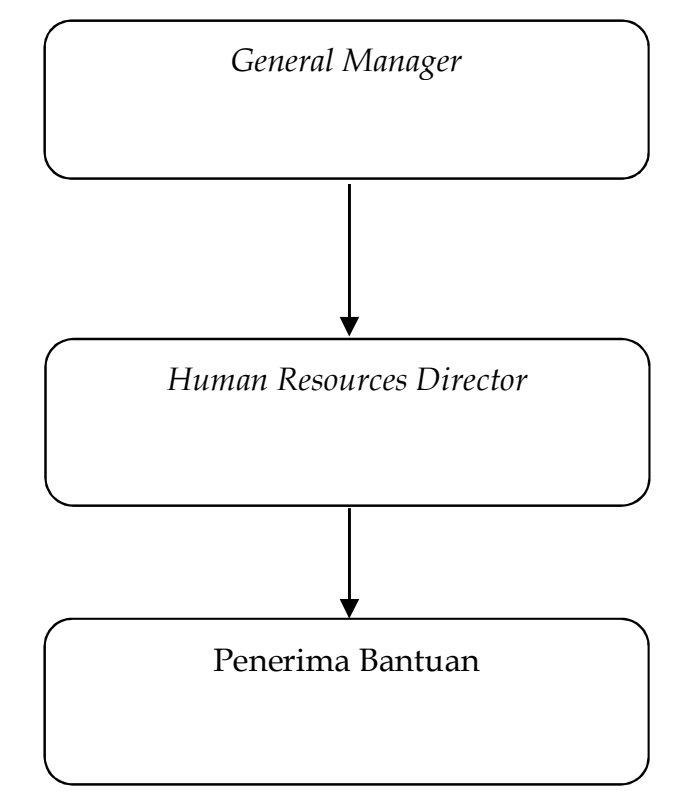

Gambar 1. Struktur Pelaksana CSR

Sumber: Human Resouces Departement Hotel Aston Kuta, 2019

Hasil penelitian mengungkapkan penerapan CSR yang dilakukan oleh Hotel Aston Kuta dari tahun 2015 sampai dengan tahun 2020 dalam beberapa bentuk, mulai dari kegiatan sosial kepada karyawan hingga kegiatan CSR yang mengarah pada lingkungan masyarakat sekitar. Kegiatan-kegiatan CSR bagi karyawan terkait dengan berbagai hal yang mencakup bidang ekonomi, pendidikan dan kesehatan. Kegiatan tersebut misalnya pemberian bantuan biaya pendidikan bagi putra-putri karyawan yang berprestasi. Untuk memotivasi kinerja karyawan, maka diberikan reward kepada karyawan yang berprestasi melalui the best employee tiap bulannya. Disampaikan juga bahwa pemberian kesejahteraan pada karyawan telah direncanakan dengan sebaik-baiknya untuk mendukung tercapainya tujuan perusahaan pada akhirnya. Rencana tersebut diinformasikan secara terbuka dan jelas serta tepat sasaran.

Kegiatan CSR Hotel Aston Kuta tidak hanya dilakukan oleh perusahaan sendiri, tetapi juga dilaksanakan bersama Archripelago International. Hotel Aston Kuta mengadakan bakti sosial untuk membantu para lanjut usia (jompo) dan balita yang tinggal di lingkungan Segara Kuta. Bekerja sama dengan banjar Segara Kuta dan juga puskesmas, para balita dan jompo yang tinggal di sekitar wilayah Segara Kuta diberikan pemeriksaan kesehatan secara gratis dan juga melakukan senam kesehatan jasmani (SKJ). Hotel Aston Kuta juga melaksanakan tanggung jawab sosialnya dalam bidang kesehatan melalui kegiatan donor darah di bulan Agustus yang diikuti bukan hanya oleh karyawan tetapi juga melibatkan masyarakat umum. Bentuk lain dari kegiatan CSR Hotel Aston adalah bertepatan dengan ulang tahunnya yang ke-10 mengadakan kunjungan ke desa Jungutan Bebandem Kabupaten Karangasem pada tanggal 29 Agustus 2019. Desa Jungutan merupakan salah satu desa di Karangasem yang masih memerlukan perhatian dari para donatur yang peduli dengan kondisi mereka yang masih memprihatinkan. Hotel Aston melalui perwakilan panitia pelaksana kegiatan CSR 
tersebut membawa bantuan baik berupa uang tunai maupun keperluan peralatan rumah tangga dan sembako.

Perhatian dan kepedulian terhadap lingkungan dan masyarakat sekitar menunjukkan partisipasi perusahaan dalam usaha pelestarian lingkungan untuk peningkatan kualitas hidup manusia dan lingkungan dalam jangka panjang. Usaha-usaha yang dilakukan melalui CSR juga mengurangi dampak bencana yang diakibatkan oleh kerusakan lingkungan. Hotel Aston bahkan peduli dan memberikan perhatian kepada narapidana di Lapas dengan memberikan bantuan berupa dana yang dapat digunakan untuk membantu operasional Lapas Kerobokan. Di samping itu juga, perusahaan memberikan sumbangan tetap kepada desa adat dan banjar di sekitar wilayah usaha.

Secara keseluruhan kegiatan CSR Hotel Aston Kuta berdasarkan Global Reporting Initiative (GRI) G4 disajikan dalam tabel-tabel berikut.

Tabel 1. Indikator Kinerja Ekonomi (EC)

\begin{tabular}{|c|c|c|c|c|}
\hline \multirow[b]{2}{*}{ No } & \multirow[b]{2}{*}{ Aspek } & \multirow[b]{2}{*}{ Kode } & \multicolumn{2}{|c|}{ Penerapan } \\
\hline & & & Ya & Tidak \\
\hline 1 & Katagori Ekonomi & EC1 & $\sqrt{ }$ & \\
\hline 2 & & EC2 & $\sqrt{ }$ & \\
\hline 3 & & EC3 & $\sqrt{ }$ & \\
\hline 4 & & $\mathrm{EC} 4$ & & $\sqrt{ }$ \\
\hline 5 & Keberadaan Pasar & EC5 & $\sqrt{ }$ & \\
\hline 6 & & EC6 & $\sqrt{ }$ & \\
\hline 7 & $\begin{array}{l}\text { Dampak Ekonomi Tidak } \\
\text { Langsung }\end{array}$ & EC7 & $\sqrt{ }$ & \\
\hline 8 & & EC8 & $\sqrt{ }$ & \\
\hline 9 & Praktek Pengadaan & EC9 & $\sqrt{ }$ & \\
\hline & Total Presentase & & $88,9 \%$ & $11,1 \%$ \\
\hline
\end{tabular}

Sumber: Data Penelitian, 2019

Tabel Indikator Kinerja Ekonomi (EC), menunjukkan bahwa Hotel Aston sudah menerapkan 88,9 persen berdasarkan GRI G4. Hal tersebut berarti bahwa penerapan indikator di Hotel Aston sudah dikatakan baik karena menunjukkan prosentase lebih dari 50 persen. 
Tabel 2. Indikator Kinerja Lingkungan (EN)

\begin{tabular}{|c|c|c|c|c|}
\hline \multirow[t]{2}{*}{ No } & \multirow[t]{2}{*}{ Aspek } & \multirow[t]{2}{*}{ Kode } & \multicolumn{2}{|c|}{ Penerapan } \\
\hline & & & Ya & Tidak \\
\hline 1 & Bahan & EN1 & $\sqrt{ }$ & \\
\hline 2 & & EN2 & $\sqrt{ }$ & \\
\hline 3 & Energi & EN3 & $\sqrt{ }$ & \\
\hline 4 & & EN4 & & $\sqrt{ }$ \\
\hline 5 & & EN5 & $\sqrt{ }$ & \\
\hline 6 & & EN6 & $\sqrt{ }$ & \\
\hline 7 & Air & EN7 & $\sqrt{ }$ & \\
\hline 8 & & EN8 & $\sqrt{ }$ & \\
\hline 9 & & EN9 & $\sqrt{ }$ & \\
\hline 10 & & EN10 & $\sqrt{ }$ & \\
\hline 11 & $\begin{array}{l}\text { Keanekaragaman } \\
\text { Hayati }\end{array}$ & EN11 & $\sqrt{ }$ & \\
\hline 12 & & EN12 & $\sqrt{ }$ & \\
\hline 13 & & EN13 & $\sqrt{ }$ & \\
\hline 14 & & EN14 & & $\sqrt{ }$ \\
\hline 15 & Emisi & EN15 & $\sqrt{ }$ & \\
\hline 16 & & EN16 & & $\sqrt{ }$ \\
\hline 17 & & EN17 & & $\sqrt{ }$ \\
\hline 18 & & EN18 & & $\sqrt{ }$ \\
\hline 19 & & EN19 & $\sqrt{ }$ & \\
\hline 20 & & EN20 & & $\sqrt{ }$ \\
\hline 21 & Limbah & EN21 & & $\sqrt{ }$ \\
\hline 22 & & EN22 & $\sqrt{ }$ & \\
\hline 23 & & EN23 & $\sqrt{ }$ & \\
\hline 24 & & EN24 & $\sqrt{ }$ & \\
\hline 25 & & EN25 & & $\sqrt{ }$ \\
\hline 26 & Produk dan Jasa & EN26 & & $\sqrt{ }$ \\
\hline 27 & & EN27 & & $\sqrt{ }$ \\
\hline 28 & & EN28 & & $\sqrt{ }$ \\
\hline 29 & Kepatuhan & EN29 & & $\sqrt{ }$ \\
\hline 30 & Transportasi & EN30 & & $\sqrt{ }$ \\
\hline 31 & Lain-lain & EN31 & $\sqrt{ }$ & \\
\hline 32 & $\begin{array}{l}\text { Asessment } \\
\text { Pemasok dan } \\
\text { Lingkungan }\end{array}$ & EN32 & $\sqrt{ }$ & \\
\hline 33 & & EN33 & & $\sqrt{ }$ \\
\hline 34 & $\begin{array}{l}\text { Mekanisme } \\
\text { Pengaduan } \\
\text { Masalah } \\
\text { Lingkungan }\end{array}$ & EN34 & & $\sqrt{ }$ \\
\hline & Total Presentase & & $55,8 \%$ & $44,2 \%$ \\
\hline
\end{tabular}

Sumber: Data Penelitian, 2019 
Dari tabel Indikator Kinerja Lingkungan (EN), ditunjukkan bahwa Hotel Aston Kuta sudah menerapkan indikator kinerja lingkungan 55,8 persen berdasarkan GRI G4. Angka tersebut menunjukkan bahwa penerapan indikator kinerja lingkungan sudah dilakukan dengan baik, karena memperhatikan aspekaspek lingkungan.

Tabel 3. Indikator Kinerja Hak Asasi Manusia (HR)

\begin{tabular}{|c|c|c|c|c|}
\hline \multirow{2}{*}{ No } & \multirow{2}{*}{ Aspek } & \multirow{2}{*}{ Kode } & \multicolumn{2}{|c|}{ Penerapan } \\
\hline & & & $\mathrm{Ya}$ & Tidak \\
\hline 1 & Investasi & HR1 & $\sqrt{ }$ & \\
\hline 2 & & HR2 & $\sqrt{ }$ & \\
\hline 3 & Non-diskriminasi & HR3 & $\sqrt{ }$ & \\
\hline 4 & $\begin{array}{l}\text { Kebebasan Berserikat } \\
\text { dan Perjanjian Kerja } \\
\text { Bersama }\end{array}$ & HR4 & $\sqrt{ }$ & \\
\hline 5 & Pekerja Anak & HR5 & & $\sqrt{ }$ \\
\hline 6 & $\begin{array}{l}\text { Pekerja Paksa atau Wajib } \\
\text { Kerja }\end{array}$ & HR6 & & $\sqrt{ }$ \\
\hline 7 & Praktik Pengamanan & HR7 & $\sqrt{ }$ & \\
\hline 8 & Hak Adat & HR8 & $\sqrt{ }$ & \\
\hline 9 & Asesmen & HR9 & & $\sqrt{ }$ \\
\hline 10 & $\begin{array}{l}\text { Asesmen Pemasok atas } \\
\text { Hak Asasi Manusia }\end{array}$ & HR10 & & $\sqrt{ }$ \\
\hline 11 & & & & $\sqrt{ }$ \\
\hline 12 & $\begin{array}{l}\text { Mekanisme Pengaduan } \\
\text { Masalah Hak Asasi } \\
\text { Manusia }\end{array}$ & HR12 & & $\sqrt{ }$ \\
\hline & Total Presentase & & $50 \%$ & $50 \%$ \\
\hline
\end{tabular}

Sumber: Data Penelitian, 2019

Dalam tabel indikator kinerja hak asasi manusia, Hotel Aston Kuta menerapkan 50 persen berdasarkan GRI G4. Hal ini berarti bahwa indikator hak asasi manusia pada Hotel Aston Kuta sudah dilakukan dengan cukup baik tetapi yaitu membahas sejauh mana proses hak asasi manusia telah diterapkan, insiden pelanggaran terhadap hak asasi manusia dan perubahan kemampuan stekaholders untuk mendapatkan dan menggunakan hak asasinya.

Tabel 4, memberikan informasi mengenai tingkat penerapan dari indikator kinerja social (SO). Dalam tabel indikator kinerja sosial, Hotel Aston Kuta menerapkan 54,54\% indikator kinerja sosial berdasarkan GRI G4. Angka prosentase tersebut menandakan bahwa kinerja sosial telah diterapkan dengan 
baik dan dilakukan keberlanjutan sosial yang membahas dampak organisasi terhadap wilayah dan masyarakat sekitarnya.

Tabel 4. Indikator Kinerja Sosial (SO)

\begin{tabular}{|c|c|c|c|c|c|}
\hline \multirow{2}{*}{ No } & \multirow{2}{*}{\multicolumn{2}{|c|}{ Aspek }} & \multirow{2}{*}{ Kode } & \multicolumn{2}{|c|}{ Penerapan } \\
\hline & & & & $\mathrm{Ya}$ & Tidak \\
\hline 1 & \multirow{2}{*}{\multicolumn{2}{|c|}{ Masyarakat Lokal }} & SO1 & $\sqrt{ }$ & \\
\hline 2 & & & $\mathrm{SO} 2$ & & $\sqrt{ }$ \\
\hline 3 & \multirow{3}{*}{\multicolumn{2}{|c|}{ Anti-Korupsi }} & $\mathrm{SO} 3$ & $\sqrt{ }$ & \\
\hline 4 & & & $\mathrm{SO} 4$ & $\sqrt{ }$ & \\
\hline 5 & & & SO5 & & $\sqrt{ }$ \\
\hline 6 & \multicolumn{2}{|c|}{ Kebijakan Publik } & SO6 & $\sqrt{ }$ & \\
\hline 7 & \multicolumn{2}{|c|}{ Anti Persaingan } & SO7 & $\sqrt{ }$ & \\
\hline 8 & \multicolumn{2}{|c|}{ Kepatuhan } & $\mathrm{SO} 8$ & & $\sqrt{ }$ \\
\hline 9 & $\begin{array}{l}\text { Asesmen } P \\
\text { Dampak } \\
\text { Masyarakat }\end{array}$ & $\begin{array}{r}\text { emasok atas } \\
\text { Terhadap }\end{array}$ & SO9 & $\sqrt{ }$ & \\
\hline 10 & & & SO10 & & $\sqrt{ }$ \\
\hline \multirow[t]{2}{*}{11} & $\begin{array}{l}\text { Mekanisme } \\
\text { Dampak } \\
\text { Masyarakat }\end{array}$ & $\begin{array}{r}\text { Pengaduan } \\
\text { Terhadap }\end{array}$ & SO11 & & $\sqrt{ }$ \\
\hline & \multicolumn{3}{|c|}{ Total Presentase } & $54,54 \%$ & $45,46 \%$ \\
\hline
\end{tabular}

Sumber: Data Penelitian, 2019

Tabel 5, memberikan informasi mengenai tingkat penerapan masing-masing indikator kinerja produk. Berdasarkan data pada Tabel 5, terlihat bahwa penerapan indikator kinerja produk oleh Hotel Aston Kuta hanya sebesar 33,33\%. Hal tersebut bukanlah berarti bahwa Hotel Aston Kuta tidak melaksanakan kinerja produk dengan baik.

Tabel 5. Indikator Kinerja Produk (PR)

\begin{tabular}{lllll}
\hline \multirow{2}{*}{ No } & Aspek & Kode & \multicolumn{2}{l}{ Penerapan } \\
\cline { 4 - 5 } & & Ya & Tidak \\
\hline 1 & $\begin{array}{l}\text { Kesehatan } \\
\text { Pelanggan }\end{array}$ & Keselamatan & PR1 & $\sqrt{ }$ \\
2 & & PR2 & & $\sqrt{ }$ \\
3 & Pelabelan Produk dan & PR3 & $\sqrt{ }$ \\
& Jasa & & $\sqrt{ }$ & \\
4 & & PR4 & & $\sqrt{ }$ \\
5 & & PR5 & $\sqrt{ }$ & $\sqrt{ }$ \\
6 & Komunikasi Pemasaran & PR6 & & $\sqrt{ }$ \\
7 & & PR7 & & $\sqrt{ }$ \\
8 & Privasi Pelanggan & PR8 & & $66,67 \%$ \\
9 & Kepatuhan & PR9 & & \\
& Total Presentase & & $33,33 \%$ & \\
\hline
\end{tabular}

Sumber: Data Penelitian, 2019 
Masing-masing bagian dalam indikator produk dijelaskan sebagai berikut. Indikator PR2 dan PR4 menyebutkan total jumlah insiden ketidakpatuhan terhadap peraturan dan koda sukarela terkait dampak kesehatan dan keselamatan dari produk dan jasa sepanjang daur hidup, menurut jenis. Hotel Aston Kuta tidak memiliki ketidakpatuhan terhadap peraturan yang terkait dengan produk jasa yang diberikan kepada pelanggan.

Indikator PR6 dan PR7 merupakan bagian yang saling terkait dalam komunikasi pemasaran. Bagian komunikasi pemasaran tersebut menjelaskan mengenai penjualan produk yang dilarang atau disengketakan. Hotel Aston Kuta tidak melakukan praktik yang terkait hal tersebut.

Indikator PR8 menjelaskan bagian yang merupakan nilai moneter denda yang signifikan atas ketidakpatuhan terhadap undang-undang dan peraturan terkait. Hotel Aston Kuta mentaati peraturan perundangan pemerintah terkait dengan produk dan pemasarannya.

Hotel Aston Kuta telah melaksanakan dengan baik tanggung jawabnya terhadap produk yang dihasilkan yang berhubungan dengan jasa. Penerapan terhadap indikator tersebut berpengaruh secara langsung terhadap pemangku kepentingan dan secara khusus terhadap pelanggan.

\section{SIMPULAN}

Berdasarkan hasil analisis dan pembahasan yang telah dilakukan maka dapat ditarik simpulan bahwa Hotel Aston Kuta telah menerapkan Corporate Social Responsibility (CSR) melalui berbagai kegiatan. Kegiatan CSR yang diterapkan merupakan bentuk tanggung jawab sosial perusahaan terhadap lingkungan dan sosial. Kegiatan-kegiatan Corporate Social Responsibility (CSR) yang dilakukan adalah kegiatan sosial yang meliputi aspek kesehatan, sosial dan lingkungan dengan melibatkan karyawan, tamu, lingkungan dan masyarakat.

Kegiatan CSR Hotel Aston Kuta dilaksanakan dengan memperhatikan aspek-aspek GRI G4 yang merupakan acuan pelaksanan CSR. Penerapan CSR memberikan dampak positif terhadap peningkatan citra perusahaan di mata para stakeholder, mulai dari karyawan, wisatawan yang menginap hingga masyakat pada umumnya. Semakin banyak dan sering kegiatan CSR dipublikasikan di media sosial sehingga dengan demikian akan makin meningkatkan kunjungan wisatawan ke hotel.

\section{REFERENSI}

Adams, C. A., \& McNicholas, P. (2007). Making \& Difference $\square$ : Sustainability Reporting, Acountability and Organizational Change. Accounting, Auditing and Accountability Journal, 20(3), 382-402.

Adeneye, B. Y., \& Ahmad, M. (2015). No TitleCorporate Social Responsibility and Company Performance. Journal of Business Studies Quarterly. Journal of Business Studies Quarterly, 7(1), 151-166.

Badan Pusat Statistik. (2018). Data Jumlah Akomodasi di Kabupaten Badung. 2021.

Battaglia, M., Testa, F., Bianchi, L., Iraldo, F., \& Frey, M. (2014). Corporate social responsibility and competitiveness within SMEs of the fashion industry: Evidence from Italy and France. Sustainability (Switzerland), 6(2), 872-893. https://doi.org/10.3390/su6020872 
Bhuiyan, Hoque, \& Alawad, A. (2015). Pengaruh Pengungkapan Good Corporate Governance Dan Corporate Social Responsibility Terhadap Kinerja Perusahaan Perbankan. Accounting and Finance Research, 53(9), 1689-1699.

Bryson, J. M. (2001). Perencanaan Strategi bagi Organisasi. Pustaka Pelajar Offset Yogyakarta.

Budiarti, M., \& Tri.R, S. (2018). Coporate Social Responsibility (CSR) Dari Sudut Pandang Perusahaan. Jurnal Akuntansi Universitas Kristen Petra., 7(1), 13-29. https://doi.org/10.9774/gleaf.978-1-907643-08-8_12

Budimanta, A., Prasetijo, A., \& Rudito, B. (2008). CSR, Alternatif Bagi Pembangunan Indonesia. Jakarta: ICSD.

Certo, S. ., \& Certo, S. . (2006). Modern Management. Pearson Prentice Hall United States America.

Chariri, A., \& Ghozali, I. (2007). Teori Akuntansi. Badan Penerbit Universitas Diponegoro,.

Chou, L.-C., Chang, T.-C., Darcy, J., \& Yan, Y.-C. (2017). The Impact of Social Responsibility in Corporate Performance: Evidence from Taiwan. Journal of Accounting and Finance Research, 6(2), 181-189.

Deasy, W. (2012). Peranan Corporate Social Responsibility Sebagai Upaya Pemberdayaan Masyarakat Untuk Mengurangi Kemiskinan. Jurnal Ekonomi Akuntansi Dan Manajemen, Vol. XI(No. 2), 2012.

Ernawan, E. R., Manajemen, P. S., \& Pasundan, U. (2016). Tanggungjawab Sosial Perusahaan (Corporate Social Responsibility) dalam Perspektif Kebijakan Pembangunan Pertanian. Analisis Kebijakan Pertanian, 6(2), 155-173. https://doi.org/10.21082/akp.v6n2.2008.155-173

Erni. R. Ernawan. (2010). Strategic Management $\square$ : A Stakeholder Approach. Pitman Publishing. Boston.

Gussman, S. Y., Fathonah, S., \& Wibawa, A. (2014). CSR is new feature of strongly ethical, humaneness. Jurnal Ilmu Komunikasi, 7(1).

Hariwijaya. (2017). Metodologi dan Teknik Penulisan Skripsi, Tesis E Disertasi. Elmatera.

Hossain, M., Islam, K., \& Andrew, J. (2013). Corporate social and environmental disclosure in developing countries: Evidence from Iran. Accounting and Finance Research, 4(1), 135-146. https://doi.org/10.5267/j.msl.2012.10.037

Indonesia, M. H. dan H. A. M. R. (2007). Undang-Undang Nomor 40 Tahun 2007 tentang Perseroan Terbatas.

Jeje, K. (2017). The International Journal of Humanities \& Social Studies. The International Journal of Humanities \& Social Studies., 5(7), 287-296.

Kapita, N. M. ., \& Suardana, K. . (2018). Pengaruh Corporate Social Responsibility dan Intellectual Capital Pada Reputasi Perusahaan Manufaktur. Jurnal Ilmiah Akuntansi Dan Bisnis, 12(1), 31-40.

Kitzmueller, M., \& Shimshack, J. (2012). Economic perspectives on corporate social responsibility. Journal of Economic Literature, 50(1), 51-84. https://doi.org/10.1257/jel.50.1.51

Kotler, P., \& Lee, N. (2005). Corporate Social Responsibility: Doing the Most Good for Your Company and Your Cause. John Wiley \& Sons, Ltd.

Lindawati, A. S. L., \& Puspita, M. E. (2015). Corporate Social Responsibility: Implikasi Stakeholder dan Legitimacy Gap dalam Peningkatan Kinerja 
Perusahaan. Jurnal Akuntansi Multiparadigma, 157-174. https://doi.org/10.18202/jamal.2015.04.6013

Lydia Ivana Hariyanto, M. L. G. (2018). Penerapan Tanggung Jawab Sosial Perusahaan Dan Dampaknya Terhadap Komitmen Afektif Karyawan Hotel Di Bali. Jurnal Hospitality Dan Manajemen Jasa, 6(2).

Magazine, G. R. (2019). GRI Empowering Sustainable Decision.

Mahayani, N. L. A. (2017). Prosocial Behavior Dan Persepsi Akuntabilitas Pengelolaan Dana Desa Dalam Konteks Budaya Tri Hita Karana. Jurnal Ilmiah Akuntansi Dan Bisnis, 129. https:// doi.org/10.24843/jiab.2017.v12.i02.p07

Petia, K., Thomas, L., \& Eric, M. (2017). Corporate Social Responsibility in an International Perspective: Europe, Russia and Tunisia. Journal of Economic and Business, 17(1), 11-18.

Prastowo Andi. (2012). Metode Penelitian Kualitatif dalam Perspektif Rancangan Penelitian. Ar-Ruzz Media : Yogyakarta.

Prastuti, M. C., \& Budiasih, I. G. A. N. (2019). Pengaruh Corporate Social Responsibility dan Intellectual Capital Pada Kinerja Keuangan (Studi Empiris pada Perusahaan Sektor Perdagangan yang Terdaftar di Bursa Efek Indonesia periode 2015-2017). Jurnal Ilmiah Akuntansi Dan Bisnis Universitas Udayana, 12(1).

Putri, I. G. ., Ulupui, I. G. K. ., \& Wirawati, N. G. . (2017). Pengaruh Good Corporate Gonernance Dan Budaya Tri Hita Karana Pada Kinerja Bank Perkreditan Rakyat. Jurnal Ilmiah Akuntansi Dan Bisnis Universitas Udayana, 12(1), 17-24.

Retnoningsih, H. (2017). Permasalahan CorporateSocial Responsibility (CSR) Dalam Rangka Pemberdayaan Masyarakat. Jurnal Aspirasi Pusat Pengkajian Dan Pengolahan Data., 6(2), 177-188.

Rice. (2017). Corporate Social Responsibility Disclosure: Between Profit and Ethics. Jurnal Wira Ekonomi Mikroskill, 7(1), 109-118.

Robbins, Bergman, \& StaggCoulter. (2012). Attitudes of Malaysian Tourism and Hospitality Students' towards a Career in the Industry. Asia Pacific Journal of Tourism Research, 17(3), 262-276. https://doi.org/10.1080/10941665.2011.625430

Satriyaning, I. G. ., \& Yasa, G. . (2019). Pengungkapan Corporate Social Responsibility dan Manajemen Laba. Jurnal Ilmiah Akuntansi Dan Bisnis Universitas Udayana, 2(2), 25.

Suartana, I. (2010). Akuntansi Lingkungan Dan Triple Bottom Line Accounting: Paradigma Baru Akuntansi Bernilai Tambah. Bumi Lestari, 10(1).

Sugiyono. (2015). Metode Penelitian. Salemba Empat.

Visser, W., \& Elkington, J. (2013). Cannibals with Forks. In The Top 50 Sustainability Books (Issue April). https://doi.org/10.9774/gleaf.978-1-907643-44-6_24

W, P., \& Budhisulistyawati, A. (2018). Studi Tentang CSR Di PT.MaduBaru Yogyakarta Berdasarkan Undang-Undang Nomor 49 Tahun 2007 Tentang Perseroan Terbatas. Jurnal Hukum Privat Law Universitas Sebelas Mare, 6(1), 1323.

Yudastri, N. ., Budiartha, I. ., \& Badera, I. D. . (2017). Budaya Tri Hita Karana Sebagai Pemoderasi Pengaruh Penganggaran Partisipatif, Pengendalian Anggaran Dan Standar Operasional Prosedur Pada Perilaku Disfungsional. Buletin Studi Ekonomi, 89-99. 